\title{
Bacterial biomass, heterotrophic production and utilization of dissolved organic matter photosynthetically produced in the Almeria-Oran front
}

\author{
Margarita Fernández, Micheline Bianchi, France Van Wambeke \\ Microbiologie Marine (CNRS, U.P.R. 223), Campus de Luminy, Case 907, 13288 Marseille cedex 9, France
}

(Received April 8, 1993; revised and accepted September 3, 1993)

\begin{abstract}
Bacterial biomass, bacterial production and the quantitative importance of the heterotrophic assimilation of photosynthetically produced dissolved organic carbon (PDOC) were examined in relation to the hydrodynamical and biological conditions in the Almeria-Oran front area (Alboran Sea, Western Mediterranean). Although, including all data, bacterial abundance correlated with chlorophyll $a(r=0.49)$, the bacteria/phytoplankton carbon ratio decreased in the core of the Atlantic jet. Bacterial integrated secondary production ranged from 124 to $199 \mathrm{mg} \mathrm{C}$ $\mathrm{m}^{-2} \mathrm{~d}^{-1}$. Bacterial generation times averaged $3.2 \mathrm{~d}($ S.D. $=1.3)$ in frontal sites above the pycnocline and $25 \mathrm{~d}$ $($ S.D. $=11)$ under the pycnocline. In the adjacent Mediterranean waters, bacterial generation times displayed homogenous values from the surface to $150 \mathrm{~m}$ (mean $2.7 \mathrm{~d}$; S.D. $=1.5$ ). An isolated Atlantic water mass, at the right side of the jet, showed the longest average bacterial generation times $(9.5 \mathrm{~d})$. In the chlorophyll maximum layers, percent extracellular release represented $23.5 \%$ of total net primary production in the oligotrophic sites and only $6.5 \%$ in the core of the Atlantic jet. The contribution of PDOC to bacterial production exhibited large variations (17-100\%). Dissimilarities among sites and hydrodynamical structures of the water masses were mostly observed in bacterial generation times and phytoplankton extracellular release.
\end{abstract}

\section{Introduction}

Mesoscale discontinuities such as fronts between water masses have been shown to promote localized enhancement of primary production and biomass (Falkowski et al., 1991) inducing an increase of bacterial biomass and/or production rate (Ducklow and Hill, 1985; Verheye-Dua and Lucas, 1988; Børsheim, 1990). In the Mediterranean Sea, in spite of an oligotrophic trend, biological production is locally increased by frontal systems such as the front of the Ligurian
Sea (Sournia et al., 1990; Gorsky et al., 1991), the estuarine front of the Rhône river plume (Bianchi et al., 1993), and the eddies generated from instabilities along the Algerian Current (Millot, 1987; Raimbault et al., 1993).

The role and importance of bacteria and the resulting microbial loop (Azam et al., 1983) have been considered extensively as heterotrophic bacterial activity is closely associated with primary production. Thirty to $50 \%$ of the fixed carbon can be channeled through the microbial food chain (Cole et al., 1988). Up to $50 \%$ of the bacterial 
carbon demand can be sustained by assimilation of phytoplankton extracellular release (Baines and Pace, 1991).

In addition to the enhancement of primary production, the secondary circulation associated with geostrophic fronts (i) induces particular distribution of phytoplanktonic biomass such as deep chlorophyll maximum (DCM) under very low light conditions and (ii) promotes growth of some taxonomical groups of phytoplankton (Legendre and Le Fèvre, 1989; Gould and Wiesenburg, 1990; Raimbault et al., 1993). Consequently, such changes in distribution and composition of the primary producers may induce direct consequences on bacterial secondary production.

The present study reports on the bacterial biomass, heterotrophic production and bacterial assimilation of photosynthetically-produced dissolved organic carbon (PDOC) in the eastern boundary of the Alboran Sea during the "Almofront-1" cruise (Prieur et al., 1993; Prieur and Sournia, 1994). Bacterial contribution to carbon budget was determined in the frontal zone, as well as and in the Mediterranean and Atlantic adjacent oligotrophic water masses.

\section{Material and methods}

Samples were collected during leg B of the "Almofront-1" cruise (14-27 May 1991) in the eastern Alboran Sea. Six sites across the frontal jet structure were visited from south to north (Prieur et al., 1993; Prieur and Sournia, 1994): site 2, Anticyclonic Atlantic Gyre (AAG); site 1, right side of the jet core; site 5 , left side of the jet core; site 6 , left edge of the jet; site 4 , left side of the jet corresponding to a divergence; and site 3, oligotrophic Mediterranean water (Fig. 1). Water samples were collected in 101 Niskin bottles from CTD-rosette, triggered at 12 variable depths determined according to the position of the pycnocline and DCM. Bacterial biomass and production were determined on samples collected at dawn in 6 Niskin bottles chosen close to DCM (above, into and under each of the DCM). Bacterial uptake of algal extracellular products was investigated in samples collected at noon from

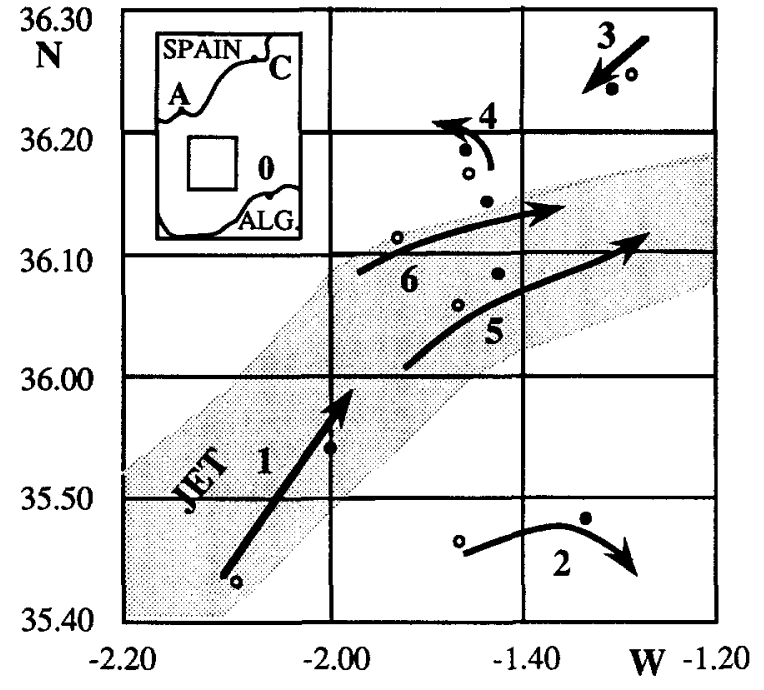

Fig. 1. Location of sampling stations during the leg $B$ of Almofront-1 cruise (14-24 May, 1991). The arrows show the drifts of the sediment traps during the study of each site identified by its number. Circles show stations sampled for bacterial biomass and production, dots show stations sampled for bacterial incorporation of PDOC. $A L G$.: Algeria, $A$ : Almeria, $C$ : Cartagena, $O$ : Oran.

the DCM (Fig. 1). Before incubations, all samples were gently sieved through a $200 \mu \mathrm{m}$ net to remove large zooplankton.

\subsection{Bacterial biomass and production measure- ments}

Bacterial abundance was determined by epifluorescence microscopy of samples preserved in $2 \%$ particle-free formalin (Porter and Feig, 1980) by using an image analysis system (Van Wambeke, 1988). During experiments for bacterial PDOC utilization, the size distribution of bacterial numbers was determined using differential filtration. Seawater samples were screened through $3 \mu \mathrm{m}$ Nuclepore $($ filters under gravity alone and bacterial counts were performed in the $<3 \mu \mathrm{m}$ filtrate.

Bacterial production rates were estimated from the rates of [methyl ${ }^{3} \mathbf{H}$ ]thymidine incorporation into cold trichloroacetic acid (TCA) insoluble material (Fuhrman and Azam, 1982) and into DNA (Wicks and Robarts, 1987). Precipitates from the 
cold-TCA treatment may include labelled proteins and molecules soluble in ethanol as phospholipids, in addition to the DNA (Moriarty, 1986). Because this nonspecific macromolecular labelling varies among water types and trophic gradients, DNA and cold-TCA precipitate labelling were systematically compared over sites and depths.

Duplicates of $40 \mathrm{ml}$ and a killed control were incubated for 2 hours with $\left.20 \mathrm{nM} \mathrm{[}{ }^{3} \mathrm{H}\right]$ thymidine (44 Ci mmol ${ }^{-1}$, Amersham $\left.{ }^{\circledR}\right)$ at the in situ temperature in the dark. Incubation was stopped by adding ice-cold TCA to a final concentration of $5 \%$ and standing for 15 minutes on ice. Each sample was then divided into two aliquots of 20 $\mathrm{ml}$ which were filtered through $0.2 \mu \mathrm{m}$ Nuclepore ${ }^{\circledR}$ to measure the rates of incorporation of thymidine into cold TCA precipitable material and into purified DNA. The filters were washed three times with ice-cold 5\% TCA, and additionnal washing with $3 \mathrm{ml}$ of ice-cold $10 \mathrm{mM} \mathrm{NaHCO}_{3}$ for filters devoted to DNAse treatment. Filters were stored at $-20^{\circ} \mathrm{C}$ until processing. Then, the filters for the measure of incorporation into cold TCA precipitable fraction were incubated $30 \mathrm{~min}$. at $100^{\circ} \mathrm{C}$ with $0.5 \mathrm{ml}$ of $0.5 \mathrm{~N} \mathrm{HCl}$, in order to minimize self-absorption by hydrolyzing nucleic acids. After cooling, $10 \mathrm{ml}$ of scintillation cocktail was added. The duplicate filters were submitted to enzymatic digestion procedures (DNAse I grade I, 3000 Kunitz units mg $^{-1}$, Boehringer ${ }^{\circledR}$ ) as in Torréton and Bouvy (1991); $2.5 \mathrm{ml}$ of a DNAse solution (final concentration $2.5 \mathrm{mg} \mathrm{l}^{-1}$ in $20 \mathrm{mM}$ morpholinopropanesulphonic acid, $0.5 \mathrm{mM}$ $\mathrm{MgCl}_{2}, 0,5 \mathrm{mM} \mathrm{CaCl}_{2}, \mathrm{pH} \mathrm{7.5)}$ was poured onto the filter. After one hour incubation at $37^{\circ} \mathrm{C}$ on a rotary shaker, the incubated solution was filtered through $0.2 \mu \mathrm{m}$ Nuclepore $($ filter. Two milliliters of the filtrate were radioassayed with $20 \mathrm{ml}$ of PCS Amersham ${ }^{\circledR}$. Control values were obtained by using the same mineral solution, but without enzyme.

Linearity of uptake was achieved for $2 \mathrm{~h}$ incubation period, as verified from time-course experiments performed in sites $1,2,3$ and 5. Concentration kinetics ( 2 to $40 \mathrm{nM}$ ) showed that $20 \mathrm{nM}$ corresponded to saturating conditions in our samples, preventing endogenous isotopic dilution.
In order to convert the measured thymidine incorporation in DNA into bacterial carbon production, the empirical approach of Kirchman et al. (1982) was applied to two characteristic types of oligotrophic and frontal waters (site 3 and site 5 , respectively). Two hundred milliliters of seawater, collected at the first DCM, were filtered through $3 \mu \mathrm{m}$ to reduce the predation pressure and diluted tenfold with $0.2 \mu \mathrm{m}$ filtered seawater. From simultaneous measurements of rates of $\left[{ }^{3} \mathrm{H}\right]$ thymidine incorporation and bacterial direct counts during $24 \mathrm{~h}$ time-course incubations, the conversion coefficient was calculated according to the Modified Derivative Method (Ducklow et al., 1992).

\subsection{Algal release of PDOC and subsequent uptake by bacteria}

The photosynthetic fixation of inorganic carbon, the subsequent carbon release and the heterotrophic assimilation of PDOC were measured by the ${ }^{14} \mathrm{C}$ technique combined with a particle size fractionation (Wolter, 1982). For each sample, 6 flasks were incubated with sodium $\left[{ }^{14} \mathrm{C}\right] b i-$ carbonate (vials 1 to 6) and 6 flasks were incubated with a $\left[{ }^{3} \mathrm{H}\right]$ amino acid mixture (vials 7 to 12).

Vials $1,2,5$ and 6 received $20 \mathrm{ml}$ of unfiltered subsample, while vials 3 and 4 received $20 \mathrm{ml}$ of 3 $\mu \mathrm{m}$ pre-filtered subsample. Two $\mu \mathrm{Ci} \mathrm{ml} ~^{-1}$ of sodium ${ }^{14} \mathrm{C}$ bicarbonate (specific activity $52.4 \mathrm{mCi}$ $\mathrm{mmol}^{-1}$, Amersham $($ ) were added in each of these 6 vials. The blank (zero time control, vial 6) was immediately filtered. Vials 1 to 4 were incubated, for $6 \mathrm{~h}$ (afternoon half day), at $15^{\circ} \mathrm{C}$ in a photosynthetron-type incubator (Lewis and Smith, 1983) with neutral screens simulating depth light. Vial 5 was the non-photosynthetic fixation control and was incubated in the dark. At the end of the incubation period, each vial was filtered sequentially through $3 \mu \mathrm{m}$ (Nuclepore ${ }^{\circledR}$ filters, gravity filtration) and $0.2 \mu \mathrm{m}$ (Nuclepore ${ }^{\circledR}$ filters, vacuum $<150 \mathrm{~mm} \mathrm{Hg}$ ). Two $10 \mathrm{ml}$ aliquots of the filtrate from the $0.2 \mu \mathrm{m}$ filtration containing the residual exudate were acidified with $\mathrm{HCl}$ $(\mathrm{pH}<2)$ and purged with air ( 2 hours). Then, 8 
$\mathrm{ml}$ of this acidified filtrate received $10 \mathrm{ml}$ PCS scintillation cocktail (Amersham ${ }^{\circledR}$ ) and were radioassayed.

The activities on the $0.2 \mu \mathrm{m}$ filters include bacterial assimilation of ${ }^{14} \mathrm{C}$-labelled extracellular organic carbon and photosynthetic assimilation of small algae. Pre-filtered controls (vials 3 and 4) were used to estimate the bicarbonate uptake in the $0.2-3 \mu \mathrm{m}$ fraction. Water from the original composite samples was pre-filtered through a 3 $\mu \mathrm{m}$ filter, incubated as described earlier, and subsequently $0.2 \mu \mathrm{m}$ filtered. The radioactivity on $0.2 \mu \mathrm{m}$ filters from vials 3 and 4 was assumed to be due to small algae (picoplankton) and was substracted from the radioactivity on the $0.2 \mu \mathrm{m}$ filter of vials 1 and 2 . The difference represents the radioactivity associated to heterotrophic assimilation of PDOC by bacteria passing through 3 $\mu \mathrm{m}$ filters. Some large, clumped and/ or particle-attached bacteria were also retained on the $3 \mu \mathrm{m}$ filter, however. To correct for heterotrophic assimilation of PDOC in this upper fraction, the size distribution of heterotrophic activity (as determined with $\left[{ }^{3} \mathrm{H}\right]$ amino acid assimilation) was also measured during 2-hour incubations. This correction assumed identical size distributions of extracellular organic carbon uti- lization and amino acid uptake. $\left[{ }^{3} \mathrm{H}\right]$ amino acid mixture (ref TRK 440, Amersham ${ }^{\circledR}$ ) was added in $20 \mathrm{ml}$ subsamples (vials 7 to 12) at a final concentration of $2 \mathrm{nM}$. Vials were incubated for 2 hours in the same conditions as ${ }^{14} \mathrm{C}$-incubated flasks. Formalin was used for killed blanks (vials 9 and 12) and for stopping incubation. Duplicates (vials 7 and 8 ) were filtered through $3 \mu \mathrm{m}$. The two other duplicates (vials 10 and 11) were 0.2 $\mu \mathrm{m}$ filtered. Filters were rinsed several times with $0.2 \mu \mathrm{m}$ filtered seawater. The following conventions were used:

- Total net PDOC release $=$ apparent PDOC release + bacterial assimilation of PDOC.

- Total net primary production $=$ particulate phytoplankton production + total net PDOC release.

- Percent extracellular release $(P E R)=100 \times$ total net PDOC release/total net primary production.

During the study of bacterial assimilation of phytoplankton exudates, amino acid uptake rates were estimated using $\left[{ }^{3} \mathrm{H}\right]$ amino acid assimilation. Dissolved free amino acids (DFAA) were measured according to the HPLC method of Lindroth and Mopper (1979).

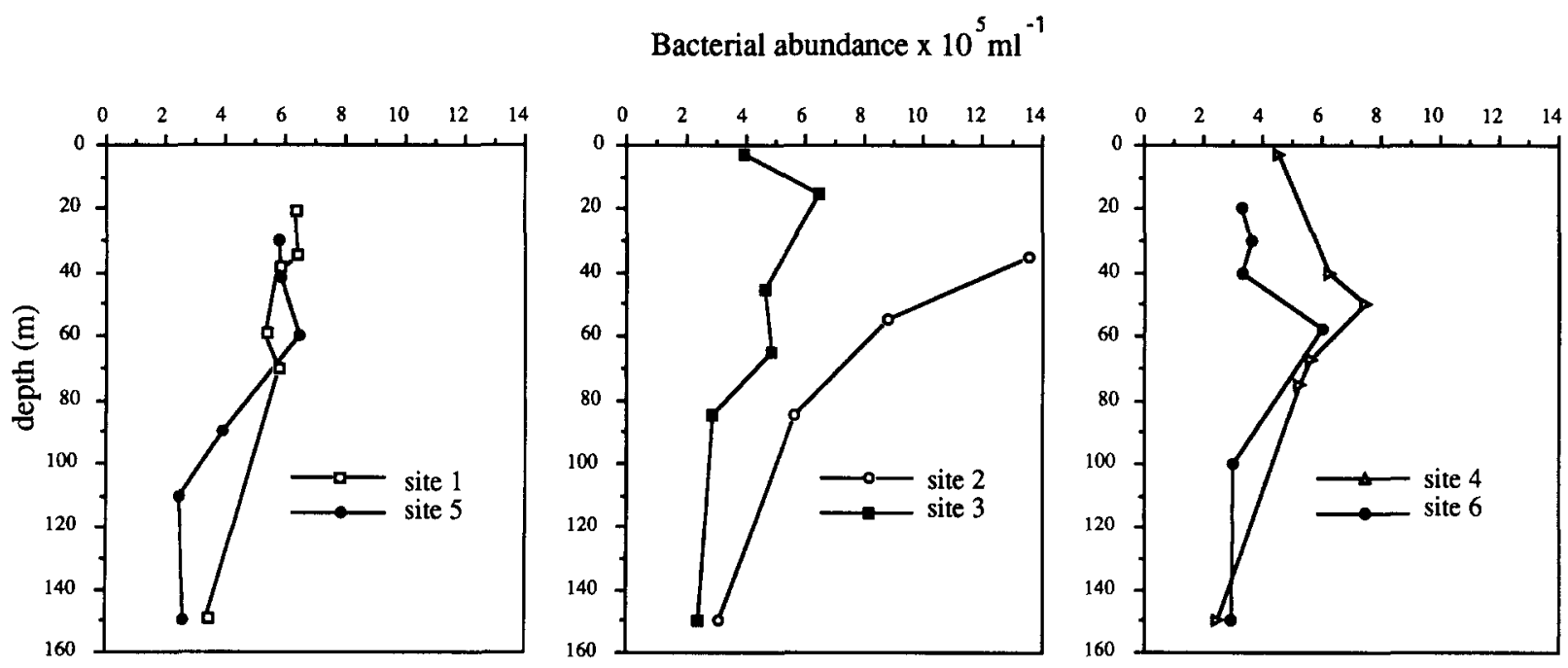

Fig. 2. Profiles of bacterial abundance at the six sites investigated. 


\section{Results}

\subsection{Biomass and heterotrophic production}

The vertical profiles of bacterial abundance in the euphotic zone showed a strong contrast between the Mediterranean site 3 and the Atlantic site 2 which displayed respectively low ( 2.3 to $6.4 \cdot 10^{5} \mathrm{ml}^{-1}$ )and high (up to $13.5 \cdot 10^{5} \mathrm{ml}^{-1}$ ) densities of bacteria (Fig. 2). Intermediate values were observed in the jet core sites ( 1 and 5). In sites 4 and 6 (north of the jet), bacterial abundance peaked at the DCM ( 7.4 and $6.0 \cdot 10^{5}$ bacteria $\mathrm{ml}^{-1}$, respectively). Bacterial numbers, including all data, were correlated (linear correlation coefficient $0.49, p<0.01$ ) with the Chl. $a$ concentration (HPLC data, Claustre et al., 1994). At the DCM, bacterial counts in unfiltered and in $>3 \mu \mathrm{m}$ fraction were never statistically different. In contrast, in surface sample of AAG, bacteria retained by $3 \mu \mathrm{m}$ filter represented $15 \%$ of the total counts (results not shown).

The amount of radioactivity incorporated into DNA ranged from 25 to $72 \%$ of total macromolecular labelling (mean $=52.2 ;$ S.D. $=12.5 ; n$ $=32$ ). No consistent relationship was observed between this ratio and sites or depths. Furthermore, no significant correlation (Spearman rank correlation) was obtained, neither with bacterial numbers ( $p>0.05 ; n=32$ ), nor with trophic gradient as reflected with chlorophyll $a$ ( $p>0.05$; $n=32$ ). In addition, inside each site, variability (Standard deviation/mean) of this ratio was always greater than $21 \%$ except for both frontal sites ( $12 \%$ and $7 \%$ for sites 5 and 1 respectively), which were also sites of a strong bacterial production. The ratio of radioactivity incorporated into DNA versus TCA-precipitable fraction (DNA/ TCA) was inversely correlated to thymidine incorporation rate in DNA $(r=0.49 ; p<0.01)$. Such observations have already been made on more eutrophic river waters (Jeffrey et al., 1990) and hypertrophic coastal waters (Robarts et al., 1986). A detailed analysis of this relationship showed that the variability of the ratio DNA/ TCA was higher $(27 \%)$ for low production rates $\left(<3\right.$ pmol $1^{-1} \mathrm{~h}^{-1}$ into DNA) than for high production rates $(9 \%)$. Furthermore, we observed in our calibration experiments that a very large proportion $(>80 \%)$ of exogenous thymidine was incorporated into DNA rather than into other macromolecules. TCA-based conversion factors would give overestimates of bacterial production. Consequently, we used DNA-based conversion factors and thymidine incorporation rates into DNA for our estimates of bacterial biomass production.

The rates of thymidine incorporation into DNA

Thymidine incorporation rates ( pmol $1^{-1} \mathrm{~h}^{-1}$ into DNA)
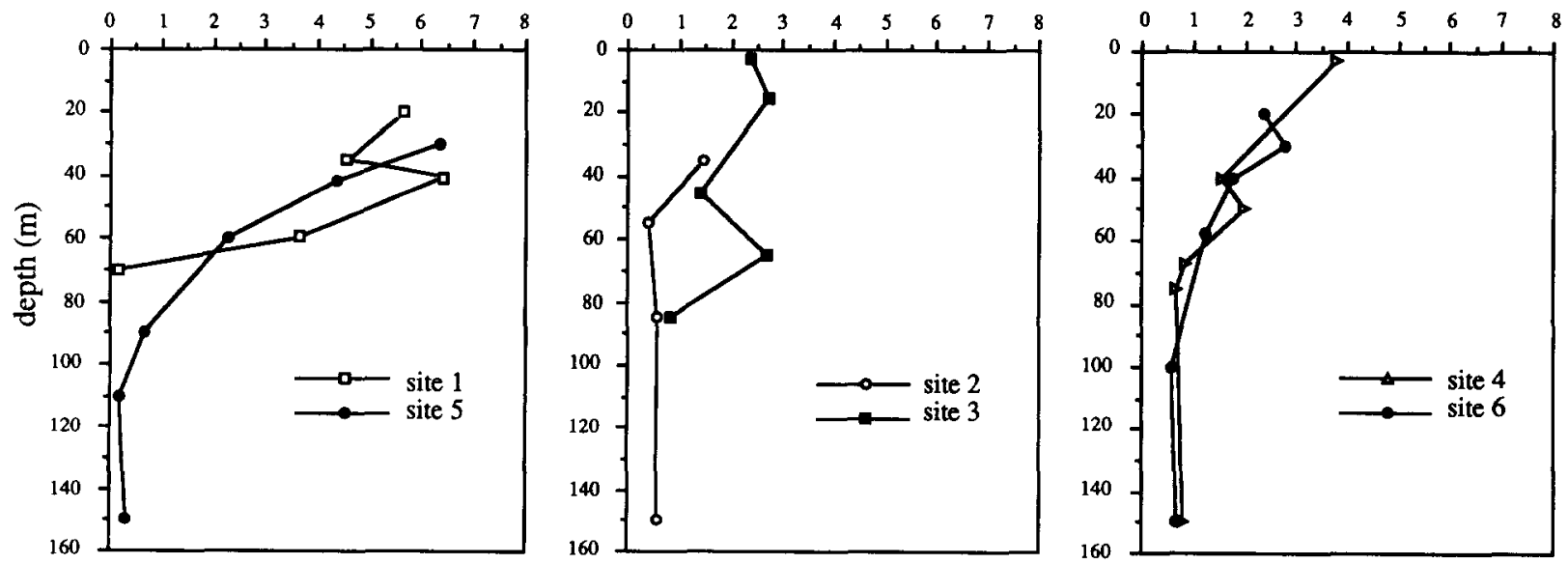

Fig. 3. Profiles of thymidine incorporation rates at the six sites investigated. 
(Fig. 3) were not related to bacterial abundance. In both sites of the jet core ( 1 and 5), the maxima of bacterial production and bacterial counts did not coincide. In these sites, bacterial production was three times higher than in the oligotrophic sites ( 3 and 2 ). This increased production was obviously demonstrated in the first $50-80 \mathrm{~m}$, corresponding to the low salinity surface water. Site 2 (Atlantic) displayed, concomitantly, the highest bacterial numbers $\left(>10^{6}\right.$ cells $\left.\mathrm{ml}^{-1}\right)$ and the lowest thymidine incorporation rates (0.07-1.4 pmol $1^{-1} \mathrm{~h}^{-1}$ of thymidine incorporated into DNA).

The conversion factor for the calculation of bacterial production from rates of $\left[{ }^{3} \mathrm{H}\right]$ thymidine incorporation into DNA was established on the consideration of: (1) two values of 0.68 and 1.81 $\times 10^{18}$ cells per mol incorporated into DNA at chlorophyll maximum layers in sites 1 and 3, respectively, (2) an average bacterial biovolume of $0.1 \mu \mathrm{m}^{3}$ obtained from the two calibration experiments and (3) a biovolume-carbon conversion factor of $0.2 \mathrm{pg} \mathrm{C} \mu \mathrm{m}^{-3}$ (Simon and Azam, 1989). The conversion factors were of 13.6 and $36.2 \mu \mathrm{g} \mathrm{C}$ per $\mathrm{nmol}$ of thymidine incorporated into DNA, for frontal sites (1 and 5) and other sites $(2,3,4,6)$, respectively. A similar tendency (conversion coefficient lower in coastal waters than in offshore area) has been already observed (Fuhrman and Azam, 1982). In terms of carbon, bacterial production showed the same vertical distribution than thymidine incorporation rates data inside the frontal sites 1 and 5 . In contrast, differences of bacterial production among sites 2 , 3,4 and 6 over sites 1 and 5 were attenuated when expressed in carbon. Bacterial carbon production at the various depths ranged between 3-87 ng C $\mathrm{l}^{-1} \mathrm{~h}^{-1}$ (site 1, right side of jet core); 3-52 $\mathrm{ng} \mathrm{Cl}^{-1} \mathrm{~h}^{-1}$ (site 2, AAG); 30-99 $\mathrm{ng} \mathrm{Cl}^{-1}$ $\mathrm{h}^{-1}$ (site 3, Mediteranean waters); 24-136 ng C $\mathrm{l}^{-1} \mathrm{~h}^{-1}$ (site 4 , subsurface divergence, left of the jet); 2-86 $\mathrm{ng} \mathrm{C}^{-1} \mathrm{~h}^{-1}$ (site 5, left side of the jet core); 2-101 ng C ${ }^{-1} \mathbf{h}^{-1}$ (site 6 , left edge of the jet). In frontal sites, however, a contrast was still observed between less saline water (above the pycnocline) and deeper waters; this also applies to bacterial generation times.

In both frontal sites, bacterial generation times dropped drastically under the pycnocline: from 2.6 to $32 \mathrm{~d}$ in site 1 , and from 3.6 to $22 \mathrm{~d}$ in site 5 (both comparisons statistically different, Student t test, $p<0.05$ ). In the adjacent areas, shorter generation times were observed, but they concerned the entire euphotic zone ( 3 to $150 \mathrm{~m}$ ): mean generation time was $2,3.5$ and $2.5 \mathrm{~d}$ in sites 3,4 and 6 , respectively. On the contrary, in the AAG (site 2), where simultaneously bacterial biomasses were high and production rates were low, we observed the highest bacterial generation time of $9.5 \mathrm{~d}$ in the upper $150 \mathrm{~m}$.

Table 1

Amino acid uptake: Total heterotrophic activity measured by $\left[{ }^{3} \mathrm{H}\right]$-amino acid incorporation and percentage of heterotrophic activity included in the $>3 \mu \mathrm{m}$ fraction; DFAA concentration of dissolved free amino acids. DCM1: first deep chlorophyll maximum, DCM2: second deep chlorophyll maximum

\begin{tabular}{|c|c|c|c|c|c|}
\hline \multirow[t]{2}{*}{ Site } & \multirow[t]{2}{*}{ Depth } & \multicolumn{2}{|c|}{ Amino acid uptake } & \multirow{2}{*}{$\begin{array}{l}\text { DFAA } \\
\left(\mathrm{nmol} \mathrm{l}^{-1}\right)\end{array}$} & \multirow{2}{*}{$\begin{array}{l}\text { Bacterial counts } \\
10^{5}{\text { bacteria } \mathrm{ml}^{-1}}^{-1}\end{array}$} \\
\hline & & $\begin{array}{l}\text { Rate } \\
\text { nmol } \mathbf{l}^{-1} h^{-1}\end{array}$ & $\%>3 \mu \mathrm{m}$ & & \\
\hline \multirow[t]{2}{*}{1} & DCM1 $50 \mathrm{~m}$ & 1.51 & 19 & 175 & 7.06 \\
\hline & DCM2 $100 \mathrm{~m}$ & 5.08 & 10 & 248 & 6.49 \\
\hline \multirow[t]{2}{*}{2} & surface $3 \mathrm{~m}$ & 3.04 & 14 & 327 & 10.98 \\
\hline & DCM1 55 m & 4.90 & 2 & 189 & 7.15 \\
\hline \multirow[t]{2}{*}{3} & surface $3 \mathrm{~m}$ & 2.45 & 6 & 382 & 4.18 \\
\hline & DCM1 $62 \mathrm{~m}$ & 1.15 & 7 & 133 & 4.54 \\
\hline \multirow[t]{2}{*}{4} & DCM1 $31 \mathrm{~m}$ & 3.88 & 6 & 475 & 6.88 \\
\hline & DCM2 $60 \mathrm{~m}$ & 0.79 & 7 & 167 & 7.42 \\
\hline 5 & DCM1 $33 \mathrm{~m}$ & 2.06 & 5 & 163 & 6.07 \\
\hline \multirow[t]{2}{*}{6} & surface $10 \mathrm{~m}$ & 2.26 & 11 & 389 & 4.83 \\
\hline & DCM1 $50 \mathrm{~m}$ & 1.28 & 5 & 425 & 4.89 \\
\hline
\end{tabular}


Most of the amino acid assimilation (90-95\%) was realized by free-living bacteria or by bacteria attached on particles smaller than $3 \mu \mathrm{m}$ (Table 1). The participation of fraction $>3 \mu \mathrm{m}$ to heterotrophic activity was highest in $50 \mathrm{~m}$ layer of site $1(19 \%)$ and in surface waters of site $2(14 \%)$. Whereas DFAA concentrations above $50 \mathrm{~m}$ depth were low in both frontal sites (1 and 5), as compared to the other sites, total amino acid assimilation rates did not show any contrast among sites or depths investigated and ranged from 0.8 to 5 nmol $\mathrm{l}^{-1} \mathrm{~h}^{-1}$ (Table 1).

\subsection{Algal release of dissolved organic carbon and subsequent bacterial uptake}

For all samples, total net primary production measured in conditions simulating DCM lightening varied in a limited range $\left(0.2-0.7 \mathrm{mg} \mathrm{C} \mathrm{m}^{-3}\right.$ $\mathrm{h}^{-1}$; Fig. 4). In contrast, the photosynthetic responses of samples from the first and/or second
DCM, incubated under saturating light conditions, were very different (Fig. 4) from that observed when incubated under $1 \%$ light (in situ simulated conditions). The highest increase of photosynthetic activity was observed in the first DCM of both frontal sites (enhancement factor 5.4 and 4.7 for sites 1 and 5 , respectively).

The repartition of the $\left[{ }^{14} \mathrm{C}\right]$ label among the three fractions (particulate autotrophic, particulate heterotrophic and dissolved) showed an extracellular release in all sites, whatever the intensity of the total net primary production. Ranges of apparent PDOC release rates were 0.019-0.163 $\mathrm{mg} \mathrm{C} \mathrm{m} \mathrm{m}^{-3} \mathrm{~h}^{-1}$ for saturating light conditions and $0.002-0.041 \mathrm{mg} \mathrm{C} \mathrm{m}^{-3} \mathrm{~h}^{-1}$ for simulated in situ light conditions. The activity of microzooplankton (sloppy feeding, excretion) included in incubation flasks may contribute to enhanced release of $\mathrm{PDO}^{14} \mathrm{C}$ (Jumars et al., 1989), although the small incubated volume $(20 \mathrm{ml})$, and the $200 \mu \mathrm{m}$ prefiltration would reduce such contribution.

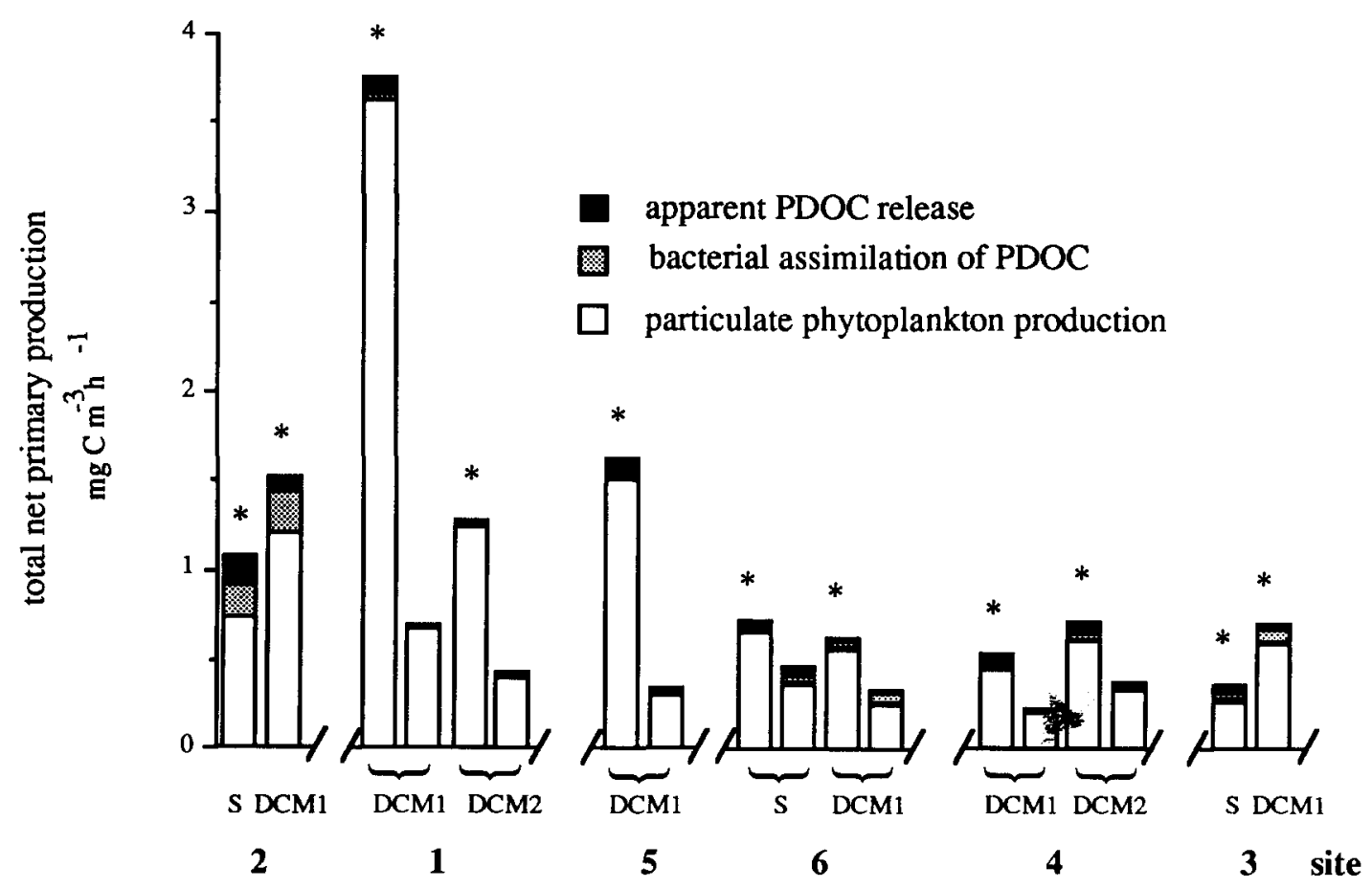

Fig. 4. Total net primary production (particulate phytoplankton production + bacterial assimilation of PDOC + apparent PDOC release) measured in samples from $\mathrm{S}=$ surface, $\mathrm{DCM} 1=$ first chlorophyll maximum, DCM2 = second chlorophyll maximum. Samples were incubated in light saturating conditions $\left(^{*}\right)$ or "simulated in situ" conditions. See Table 1 for depths. 
Percent extracellular release (PER) showed a great variability between sites and light conditions (Fig. 5). The greatest percentage release was obtained in the most oligotrophic sites 2 and $3(21-32 \%$ and $15-23 \%$, respectively). On the contrary, PER values were small in frontal sites (site 1: 2-3\%; site 5: 5-11\%).

The presence of picophytoplankton passing through $3 \mu \mathrm{m}$ filters would lead to an overestimation of the bacterial uptake of PDOC. At each experiment a correction was attempted by comparing carbon fixation in pre- and post-filtered samples incubated with $\mathrm{NaH}^{14} \mathrm{CO}_{3}$. But, in four of eighteen experiments, this correction resulted in a negative bacterial uptake of PDOC, as an higher activity was found on the $0.2 \mu \mathrm{m}$ filters from $>3 \mu \mathrm{m}$ samples (vials 3 and 4) than in those incubated with the whole water (vials 1 and 2). These samples were not considered for bacterial assimilation of exudates. Such a methodologi- cal artifact has been already observed (Søndergaard et al., 1985) and is mainly due to an important contribution of $<3 \mu \mathrm{m}$ size phytoplankton to photosynthesis. The measurement of size-fractionated productivity by Videau et al. (1994) indicated also that the photsynthesis activity was mainly due to "small" size phytoplankton in sites 2,3 and 6 at the DCM. Then, 0.8 or $1 \mu \mathrm{m}$ filters would be more appropriate in more oligotrophic areas (Søndergaard et al., 1985), where nano- and picophytoplankton dominate.

For the other data, bacterial assimilation of excreted material ranged from 21 to $78 \%$ (mean $=45 ; n=14$ ) of the total net release during a $6 \mathrm{~h}$ of incubation period. In the oligotrophic sites (2 and 3 ), about half (mean $=53.8 ;$ S.D. $=17 ; n=4)$ of the excreted carbon was assimilated by the heterotrophic bacteria. This percentage decreased in frontal sites 1 and 5 (mean $=30.5$; S.D. $=9.5 ; n=3$ ).

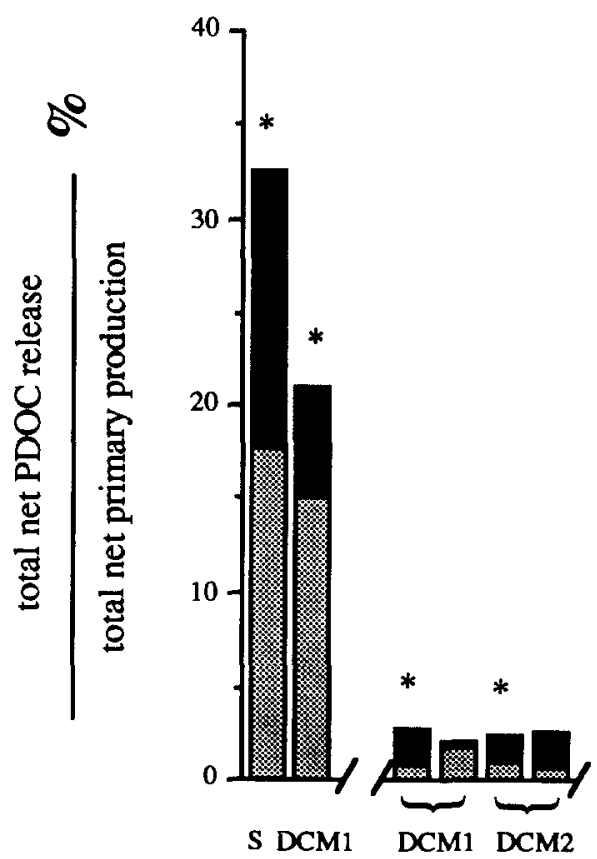

2 1

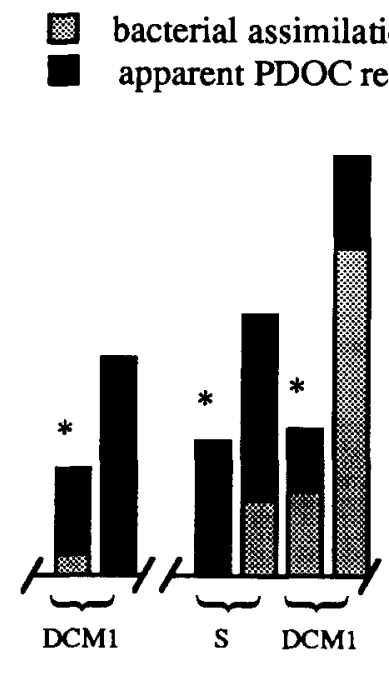

5

6

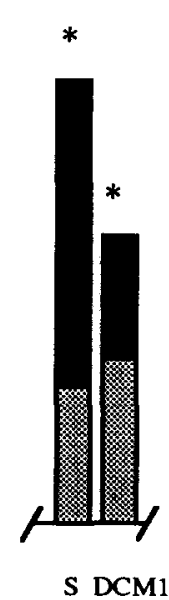

3 site

Fig. 5. Bacterial uptake of algal extracellular products. Percentage extracellular release measured in samples from $S=$ surface, DCM1 = first chlorophyll maximum, DCM2 = second chlorophyll maximum. Samples were incubated in light saturating $(*)$ and/or or "simulated in situ" conditions. See Table 1 for depths. 


\section{Discussion}

\subsection{Bacterial biomass and production versus trophic gradients}

In the Almeria-Oran frontal area, bacterial numbers were of the same order of magnitude than in other Mediterranean fronts: the Rhône River plume (Soto et al., 1993), the Ligurian front (Van Wambeke and Fernández, unpubl. data) and a warm core eddy in the Eastern Mediterranean (Zohary and Robarts, 1992). At comparable space scales (geostrophic front), bacterial numbers ranged from 0.3 to $2310^{5}$ bacteria $\mathrm{ml}^{-1}$ in a Gulf Stream front (Børsheim, 1990) and 3 to $610^{5}$ bacteria $\mathrm{ml}^{-1}$ in warm-core Gulf Stream rings (Peele et al., 1985).

Considering large time and large space scales, Cole et al. (1988) described bacterial numbers as globally correlated to chlorophyll $a$ content. In the present study, taking into account overall samples, bacterial abundance was correlated with Chl. $a(r=0.49)$. At the contrary, lack of correlation has been observed in other frontal systems (Gulf Stream front: Børsheim, 1990; warm-core rings: Ducklow, 1984).

Nevertheless, considering the results site by site, i.e. smaller scales, and assuming $\mathrm{C} / \mathrm{Chl}$. $a$ ratio $=50$ (Fuhrman et al., 1989), the bacteria/ phytoplankton carbon ratio decreased from 0.73 (Atlantic water, site 2) and 0.87 (Mediterranean water, site 3) to 0.12 and 0.26 (jet sites 1 and 5, respectively). Thus, as described by Cho and Azam (1990), the participation of bacteria to the phytoplankton biomass decreased as the trophic gradient increased. In addition, the relative proportions of phytoplankton and bacterioplankton reflect the age of the water mass (Verheye-Dua and Lucas, 1988). High bacterial biomass/ phytoplankton ratios are generally demonstrated in "old" water masses characterized by senescent phytoplankton, as it was the case for the AAG in site 2. Whatever the studied sites, the bacterial biomass was smaller than the phytoplankton biomass in the upper layers (above $150 \mathrm{~m}$ ), in contrast to the general trend described in oceanic waters (Fuhrman et al., 1989).

Considering the euphotic zone, bacterial generation times showed no differences among sites.
Nevertheless their study revealed the originality of the AAG waters, in which bacterial productivity was very low (bacterial generation time $9.5 \mathrm{~d}$ ).

Long doubling times (ca $50 \mathrm{~d}$ ) were observed in the Levantine Basin of the Eastern Mediterranean Sea (Zohary and Robarts, 1992). Fuhrman et al. (1989) recorded also bacterial doubling times higher than $10 \mathrm{~d}$ in euphotic zone of Sargasso sea. At the opposite, using a pulse labelling technique, LaRock (1987) cited extremely short bacterial generation times (down to $5 \mathrm{~h}$ ) in the Almeria-Oran zone itself. According to this author, only $1 \%$ of the bacterial population was active. In our calibration experiments, we observed extended lag phases before bacterial proliferation: $9 \mathrm{~h}$ on site $5,15 \mathrm{~h}$ on site 3 and $>24 \mathrm{~h}$ on site 2 . These results also argue for a minor fraction of productive population in site 2 (Güde, 1990; Güde et al., 1991).

\subsection{Phytoplankton excretion and bacterial utiliza- tion of PDOC versus frontal situation}

The percentage of algal extracellular release was clearly influenced by the fertilisation linked to the front-jet system. In frontal sites 1 and 5, the algal population was in a good physiological state as proved by low PER (site 1: $2-3 \%$; site 5: $5-11 \%$ of the total net primary production at the DCM). A greater release (15-32\%) was noted in the two oligotrophic sites ( 2 and 3), of Atlantic and Mediterranean origin respectively, although their water masses displayed different hydrological features. A great variability of PER is observed along the primary productivity gradient (Baines and Pace, 1991). In oligotrophic areas, the proportion of total photosynthate released is usually greater than in more eutrophic areas, as shown in this work. Taxonomic composition of phytoplanktonic populations, nutrient limitation, and phase of growth (Wolter, 1982; Lancelot, 1983; Jensen, 1984) have been demonstrated to contribute to the enhancement of PER in oligotrophic areas.

The contribution of PDOC uptake to bacterial carbon demand was estimated for the 5 sets of data available on bacterial assimilation rates of PDOC at in situ-light simulated conditions, in 
spite of some technical and biological considerations which have to be taken into account. Because of the time needed for experimental work on board, bacterial production and PDOC assimilation were measured on samples from two CTD respectively taken at sunrise and at noon. This influence of time delay between sampling could be lowered, for this comparison between sites, as the same protocol was applied each time. On the other hand, one may note that thymidine incorporation (bacterial production) is not systematically coupled with carbon uptake (Chin-Leo and Kirchman, 1990).

Estimates of PDOC uptake contribution to bacterial carbon demand are scarce in the literature. Assuming an average value of $50 \%$ respiration of $\mathrm{PDO}^{14} \mathrm{C}$ (Chrost and Faust, 1983; Coveney and Wetzel, 1989), it was calculated that bacterial PDOC uptake $\left(0.006-0.11 \mu \mathrm{g} \mathrm{C}^{-1} \mathrm{~h}^{-1}\right)$ contributed from 17 to $100 \%$ of the bacterial carbon demand (calculated from bacterial production on an hourly basis). High contribution of PDOC uptake has already been observed (Sundh and Bell, 1992). In sites 1 and 6 (sides of the jet), participation of extracellular release to bacterial carbon demand was higher in the second DCM $(100 \%)$ than in the first DCM (17-19\%). In the oligotrophic adjacent sites 2 and 3 , the only comparison available concerned surface waters and demonstrated an higher participation of extracellular release to bacterial carbon demand in Atlantic site $2(100 \%)$ than in the Mediterranean site $3(29 \%)$. In this $A A G$, an increased utilization of PDOC for the bacterial production argued for a great participation of the microbial loop on the turnover of the organic matter inside the photic layer. Furthermore, this site was characterized by a phytoplanktonic population dominated by dinoflagellates representative of regenerated primary production (Videau et al., 1994) and specific lipid metabolism (Gérin and Goutx, 1994).

Up to $72 \%$ of the PDOC was assimilated during the incubation period. Coupling between the production of easily usable organic compounds and their incorporation into biomass by heterotrophic bacteria showed high turnover of PDOC in AAG (site 2) and Mediterranean water (site 3). If concomitant high percentage of phyto- plankton release and high bacterial turnover rates of PDOC, as observed in the DCM layers, occurred in the entire euphotic zone, it would counterbalance the lower fluxes of primary production measured in these oligotrophic areas.

Total bacterial production throughout the euphotic zone $(150 \mathrm{~m})$, as calculated by integrating the depth profiles after straight line interpolation between the measurements, varied from 124 to $199 \mathrm{mg} \mathrm{C} \mathrm{m}^{-2} \mathrm{~d}^{-1}$. These values are on the same order of magnitude than a mean of $204 \mathrm{mg} \mathrm{C}$ $\mathrm{m}^{-2} \mathrm{~d}^{-1}$ obtained in the Gulf Stream front in October by Børsheim (1990), although the range obtained by this author (79-1289 $\mathrm{mg} \mathrm{C} \mathrm{m}^{-2} \mathrm{~d}^{-1}$ ) was greater. The corresponding bacterial carbon demand (assuming 50\% of bacterial growth yield) represented 64 and $47 \%$ of the integrated primary production in sites 4 (left side of the jet) and 3 (Mediterranean water), respectively. On the contrary, only a minor fraction of the integrated primary production corresponded to the bacterial carbon demand in the jet sites 1 and 5 (16 and $28 \%$, respectively), and also in site 6 (18\%). The latter showed also, as in the jet, an enhanced integrated primary production (Videau et al., 1994). A median value ( $28 \%$ ) was obtained in AAG waters (site 2). In a broad cross-system overview, Cole et al. (1988) defined that about $40 \%$ of primary production fluxes through bacteria in the photic zone.

Considerable parts of the carbon produced by algae in the jet core were not used by the local pelagic bacteria and their associated microbial loop, but were lost from the productive frontal site by particulate flux export. Enhanced sources of algal export were vertical sinking (Peinert and Miquel, 1994) and copepod grazing (Thibault et al., 1994). Both these export sources were selective and did not concern heterotrophic bacteria which sayed within the water mass and were dependent mostly on dissolved organic matter source, as free living bacteria were dominant.

\section{Conclusion}

Over the area investigated, bacterial abundance showed highest values in the Anticyclonic 
Atlantic gyre (site 2), and lowest in the Mediterranean site (3). Nevertheless, average values stayed overall sites around $10^{5}$ bacteria $\mathrm{ml}^{-1}$, with consequently no visible effect of frontal conditions on bacterial abundance.

Bacterial production in the upper 0-50 m layer, as measured by thymidine incorporation rates into DNA, was 3 times higher in the jet core (sites 1 and 5) than in the oligotrophic Atlantic and Mediterranean water masses. The similarity of integrated $(0-150 \mathrm{~m})$ bacterial production among the sites investigated originated from two main causes. Firstly, the use of different conversion factors, to convert thymidine incorporation rates in bacterial production, globally balanced discrepancies observed among sites. Secondly, there is no valuable reason to integrate bacterial production over the upper $150 \mathrm{~m}$ water column in frontal sites where water layers exhibit variable displacement rates.

In DCM layers, the total net PDOC represented $23.5 \%$ of total net primary production in oligotrophic sites and only $6.5 \%$ in the core of the Atlantic jet. The contribution of PDOC to bacterial production exhibited large variations (17$100 \%$ ). Highest percentages were observed in the DCM layers in frontal area and in the AAG. In these areas, an increased utilization of PDOC for the bacterial production argued for a strong participation of the microbial loop to the fate of phytoplankton production. On the contrary, in the surface layers (above the pycnocline) of the Almeria-Oran front, phytoplanktonic production was not used by the local pelagic bacteria.

\section{Acknowledgements}

This work is a contribution to the "Almofront1" cruise (April-May 1991) organized by L. Prieur and A. Sournia. Financial support came from INSU-CNRS and DRET (JGofs-France, opération "Frontal"). We are grateful to $\mathrm{H}$. Claustre for providing us pigments data, D. Mazaudier for HPLC analysis of amino acids and A. Sournia for valuable comments on the manuscript. We also thank the officers and crew of the RV L'Atalante.
M. Fernández thanks the Spanish Government for a F.P.U. fellowship.

\section{References}

Azam, F., Fenchel, T., Field, J.G., Gray, J.S., Meyer-Reil, L.A. and Thingstad, F., 1983. The ecological role of water-column microbes in the sea. Mar. Ecol. Prog. Ser., 10: $257-263$.

Baines, S.B. and Pace, M.L., 1991. The production of dissolved organic matter by phytoplankton and its importance to bacteria: Patterns across marine and freshwater systems. Limnol. Oceanogr., 36: 1078-1090.

Bianchi, M., Gaudy, R., Goutx, M., Leveau, M., Lochet, F., Pagano, M., Soto-Mercado, Y. and Videau, C., 1993. Trophic relationships between pelagic components of a mesoscale front: The Rhône river plume front ecosystem. Ann. Inst. Océanogr., Paris., 69: 57-62.

Børsheim, K.Y., 1990. Bacterial biomass and production rates in the Gulf Stream front regions. Deep-Sea Res., 37: 1297-1309.

Chin-Leo, G. and Kirchman, D., 1990. Unbalanced growth in natural assemblages of marine bacterioplankton. Mar. Ecol. Prog. Ser., 63: 1-8.

Cho, B.C. and Azam F., 1990. Biogeochemical significance of bacterial biomass in the ocean's euphotic zone. Mar. Ecol. Prog. Ser., 63: 253-259.

Chrost, R.J. and Faust, M.A., 1983. Organic carbon release by phytoplankton: its composition and utilization by bacterioplankton. J. Plankton Res., 5: 477-493.

Claustre, H., Kerhervé, P., Marty, J.-C., Prieur, L., Videau, C. and Hecq, J.-H., 1994. Phytoplankton dynamics asociated with a geostrophic front: ecological and biogeochemical implications J. Mar. Res., 52, in press.

Cole, J.J., Findlay, S. and Pace, M.L., 1988. Bacterial production in fresh and salt water ecosystem: a cross-system overview. Mar. Ecol. Prog. Ser., 43: 1-10.

Coveney, M.F. and Wetzel, R.G., 1989. Bacterial metabolism of algal extracellular carbon. Hydrobiologia, 173: 141-149.

Ducklow, H.W., 1984. Geographical ecology of marine bacteria: Physical and biological variability at the Mesoscale. In: M.J. Klug and C.A. Reddy (Editors), Current Perspectives in Microbial Ecology. Am. Soc. Microbiol., Washington, pp. 22-31.

Ducklow, H.W. and Hill, S.M., 1985. Tritiated thymidine incorporation and the growth of heterotrophic bacteria in warm core rings. Limnol. Oceanogr., 30: 260-272.

Ducklow, H.W., Kirchman, D.L. and Quinby, H.L., 1992. Bacterioplankton cell growth and macromolecular synthesis in seawater cultures during the North Atlantic Spring Phytoplankton Bloom, May, 1989. Microbial Ecol., 24: 125-144.

Falkowski, P.G., Ziemann, D., Kolber, Z. and Bienfang, P.K., 1991. The role of eddy pumping in enhancing primary production in the ocean. Nature, 352: 55-58. 
Fuhrman, J.A. and Azam, F., 1982. Thymidine incorporation as a measure of heterotrophic bacterioplankton production in marine surface waters: Evaluation and field results. Mar. Biol., 66: 109-120.

Fuhrman, J.A., Sleeter, T.D., Carlson, C.A. and Proctor, L.M., 1989. Dominance of bacterial biomass in the Sargasso Sea and its ecological implications. Mar. Ecol. Prog. Ser., 57: 207-217.

Gérin, C. and and Goutx, M., 1994. Iatroscan-measured particulate and dissolved lipids in the Almeria-Oran frontal system (Almofront-1, leg B, May 1991). J. Mar. Syst., 5: 343-360.

Gorsky, G., Lins da Silva, N., Dallot, S., Laval, P., Braconnot, J.C. and Prieur, L., 1991. Midwater tunicates: are they related to the permanent front of the Ligurian Sea (NW Mediterranean)? Mar. Ecol. Prog. Ser., 74: 195-204.

Gould, R.W. and Wiesenburg, D.A., 1990. single-species dominance in a subsurface phytoplankton concentration at a Mediterranean Sea front. Limnol. Oceanogr., 35: 211-220.

Güde, H., 1990. Bacterial net production approaching zero a frequent phenomenon in pelagic environments? Arch. Hydrobiol. Beih. Ergebn. Limnol., 34: 165-169.

Güde, H., Jürgens, K., Parth, G. and Walser, R., 1991. Indications for low net productivity of pelagic bacterioplankton. Kiel. Meeresforsch. Sonderh., 8: 309-316.

Jeffrey, W.H., Paul, J.H., Cazares, L.H., DeFlaun, M.F. and David, A.W., 1990. Correlation of nonspecific macromolecular labelling with environmental parameters during $\left[{ }^{3} \mathrm{H}\right]$ thymidine incorporation in the waters of southwest Florida. Microbial Ecol., 20: 21-35.

Jensen, A., 1984. Excretion of organic carbon as a function of nutrient stress. In: O. Holm-Hansen, L. Bolis and R. Gilles (Editors), Lecture Notes on Coastal and Estuarine Studies. 8. Marine phytoplankton and productivity. Springer, Berlin, pp. 61-72.

Jumars, P.A., Penry, D.L., Baross, J.A., Perry, M.A. and Frost, B.W., 1989. Closing the microbial loop: dissolved carbon pathway to heterotrophic bacteria from incomplete ingestion, digestion and absorption in animals. Deep-Sea Res., 36: 483-495.

Kirchman, D., Ducklow, H. and Mitchell, R., 1982. Estimates of bacterial growth from changes in uptake rates and biomass. Appl. Environ. Microbiol., 44: 1296-1307.

Lancelot, C., 1983. Factors affecting phytoplankton extracellular release in the Southern Bight of the North Sea. Mar. Ecol. Prog. Ser., 12: 115-121.

LaRock, P.A., 1987. Bacterial and phytoplankton growth in mediterranean frontal systems. Eos, Trans. Am. Geophys. Union, 68: 1725-1726.

Legendre, L. and Le Fèvre, J., 1989. Hydrodynamical singularities as control of recycled versus export production in the oceans. In: W.H. Berger, V.S. Smetacek and G. Wefer (Editors), Dahlem Workshop on Productivity of the Ocean; Present and Past. Wiley, New York, pp. 49-63.

Lewis, M.R. and Smith, J.C., 1983. A small volume, short-incubation-time method for measurement of photosynthesis as a function of incident irradiance. Mar. Ecol. Prog. Ser., 13: 99-102.

Lindroth, P. and Mopper, K., 1979. High peformance liquid chromatographic determination of subpicomole amounts of amino acids by precolumn fluorescence derivatization with ophthaldialdehyde. Anal. Chem., 51: 1667-1674.

Millot, C., 1987. Circulation in the western Mediterranean Sea. Oceanol. Acta., 10: 143-149.

Moriarty, D.J., 1986. Measurement of bacterial growth rates in aquatic systems from rates of nucleic acid synthesis. Adv. Microbial Ecol., 9: 245-292.

Peele, E.R., Murray, R.E., Hanson, R.B., Pomeroy, L.R. and Hodson, R.E., 1985. Distribution of microbial biomass and secondary production in a warm-core Gulf-stream ring. Deep-Sea Res., 32: 1393-1403.

Peinert, R. and Miquel, J.C., 1994. The significance of frontal processes for vertical particle fluxes: a case study in the Alboran Sea (SW Mediterranean Sea). J. Mar. Syst., 5: 379-389.

Porter, K.G. and Feig, Y.S., 1980. The use of DAPI for identifying and counting aquatic microflora. Limnol. Oceanogr., 25: 943-948.

Prieur, L., Copin-Montégut, C. and Claustre, H., 1993. Biophysical aspects of "Almofront-1", an intensive study of a geostrophic frontal jet. Ann. Inst. Océanogr., Paris., 69: 71-86.

Prieur, L. and Sournia, A., 1994. "Almofront-1" (April-May 1991): an interdisciplinary study of the Almeria-Oran geostrophic front, SW Mediterranean Sea. J. Mar. Syst., 5: 187-203.

Raimbault, P., Coste, B., Boulhadid, M. and Boudjellal, B. 1993. Origin of high phytoplankton concentration in deep chlorophyll maximum (DCM) in a frontal region of the Southwestern Mediterranean Sea (Algerian Current). Deep-Sea Res. I, 40: 791-804.

Robarts, R.D., Wicks, R.J. and Sephton, L.M., 1986. Spatial and temporal variations in bacterial macromolecule labelling with [methyl- ${ }^{3} \mathrm{H}$ ]thymidine in a hypertrophic lake. Appl. Environ. Microbiol., 52: 1363-1373.

Simon, M. and Azam, F., 1989. Protein content and protein synthesis rates of planktonic marine bacteria. Mar. Ecol. Prog. Ser., 51: 201-213.

Søndergaard, M., Riemann, B. and Jörgensen, N.O.G., 1985. Extracellular organic carbon (EOC) released by phytoplankton and bacterial production. Oikos, 45: 323-332.

Sournia, A., Brylinski, J.M., Dallot, S., Le Corre, P., Leveau, M., Prieur, L. and Froget, C., 1990. Fronts hydrologiques au large des côtes françaises: Les sites-ateliers du programme Frontal. Oceanol. Acta, 13: 413-438.

Soto, Y., Bianchi, M., Martinez, J. and Vives-Rego, J., 1993. Seasonal evolution of microplanktonic communities in the Estuarine Front ecosystem of the Rhône River plume (Northwestern Mediterranean Sea). Estuarine Coastal Shelf Sci., 37: 1-13.

Sundh, I. and Bell, R.T., 1992. Extracellular dissolved organic carbon released from phytoplankton as a source of carbon 
for heterotrophic bacteria in lakes of different humic content. Hydrobiolgia, 229: 93-106.

Thibault, D., Gaudy, R. and Le Fèvre, J., 1994. Zooplankton biomass, feeding and metabolism in a geostrophic frontal area (Almeria-Oran front, Western Mediterranean). J. Mar. Syst., 5: 297-311.

Torréton, J-P. and Bouvy, M., 1991. Estimating DNA synthesis from $\left[{ }^{3} \mathrm{H}\right]$ thymidine incorporation: discrepancies among different macromolecular extraction procedures. Limnol. Oceanogr., 36: 299-306.

Van Wambeke, F., 1988. Numération et taille des bactéries planctoniques au moyen de l'analyse d'images couplée à l'épifluorescence. Ann. Inst. Pasteur (Microbiol.), 139: 261-272.

Verheye-Dua, F. and Lucas, M.I., 1988. Southern Benguela frontal region. Hydrology, phytoplankton and bacterioplankton. Mar. Ecol. Prog. Ser., 47: 271-280.
Videau, C., Sournia, A., Prieur, L. and Fiala, M., 1994. Phytoplankton and primary production characteristics at selected sites in the geostrophic Almeria-Oran front system (SW Mediterranean Sea). J. Mar. Syst., 5: 235-250.

Wicks, R.J. and Robarts, R.D., 1987. The extraction and purification of DNA labelled with [methyl- ${ }^{3} \mathrm{H}$ ]thymidine in aquatic bacterial production studies. J. Plankton Res., 9: $1159-1166$

Wolter, K., 1982. Bacterial incorporation of organic substances released by natural phytoplankton populations. Mar. Ecol. Prog. Ser., 7: 287-295.

Zohary, T. and Robarts, R.D., 1992. Bacterial numbers, bacterial production, and heterotrophic nanoplankton abundance in a warm core eddy in the Eastern Mediterranean. Mar. Ecol. Prog. Ser., 84: 133-137. 